УДК $613.6+614.8(477)$

Березовський А. П., кандидат сільськогосподарських наук,

Трус О. М., кандидат сільськогосподарських наук,

Прокопенко Е. В., кандидат сільськогосподарських наук

Уманський національний університет садівництва

\title{
СТАН ВИРОБНИЧОГО ТРАВМАТИЗМУ ТА ПРОФЕСІЙНИХ ЗАХВОРЮВАНЬ В УКРАЇНI
}

\author{
Рецензент - доктор технічних наук Г. А. Хайліс
}

Мета статmi - дослідження стану виробничого травматизму та професійних захворювань в Україні, виявлення причин травматизму та шляхів його запобігання.

Методика дослідження. Для визначення кількісних показників, щзо характеризує загальний рівень виробничого травматизму (акти за формою $H-1$ ) та професійних захворювань (акти за формою П-4) використовували статистичний метод.

Результати дослідження. Проведено порівняльний аналіз стану виробничого травматизму та професійних захворювань на виробнищтві за галузями нагляду і регіонами України за 2015-2017 роки. Встановлено, що показники виробничого травматизму, зокрема зі смертельними наслідками мають тенденцію до зниження. 2017 року кількість травмованих на виробництві порівняно з 2016 роком зменшилася на 115 осіб, а у 2015 році спостерігалося збільшення травмованих на 53 особи. Рівень смертельного травматизму в 2017 роиі зменшився на 34 і 9 осіб відповідно. Наведено дані про зростання кількості професійних захворювань на виробництві в 2017 році порівняно з попередніми роками. Встановлено, що найбільше професійних захворювань сталося в галузях добувної промисловості $i$ розробленні кар'єрів.

Елементи наукової новизни. Встановлено, що показники виробничого травматизму, зокрема. зі смертельними наслідками, мають тенденцію до зниження. Спостерігається зростання кількості професійних захворювань на виробництві порівняно з попередніми роками.

Практична значущість. Найбільш травмонебезпечними галузями залишаються сочіальнокультурна сфера та торгівля, вугільна промисловість, агропромисловий комплекс, транспорт, маиинобудування, металургійна промисловість, будівництво, хімічна промисловість та енергетика.

Ключові слова: виробничий травматизм, смертельний травматизм, галузі нагляду, нещасні випадки, професійні захворювання, охорона праці.

Березовський Андрій Павлович - кандидат сільськогосподарських наук, доцент, завідувач кафедри прикладної інженерії та охорони праці, Уманський національний університет садівництва, вул. Інститутська, 1, м. Умань, Черкаська область, 20300, Україна, e-mail: kafedrapi@gmail.com.

Трус Олександр Миколайович - кандидат сільськогосподарських наук, доцент, доцент кафедри прикладної інженерії та охорони праці, Уманський національний університет садівництва, вул. Інститутська, 1, м. Умань, Черкаська область, 20300, Україна, e-mail: alex_trus@ukr.net.

Прокопенко Едуард Васильович - кандидат сільськогосподарських наук, доцент, доцент кафедри прикладної інженерії та охорони праці, Уманський національний університет садівництва, вул. Інститутська, 1, м. Умань, Черкаська область, 20300, Україна, e-mail: proked@ukr.net.

Постановка проблеми. Виробничий процес будь-якої технологічної складності, організований у тій або тій галузі промисловості, сфері послуг, управління і реалізації продукції, тісно пов'язаний із ризиком для життя і здоров'я працівників. Виробничий травматизм давно став актуальною проблемою, як у всіх країнах світу, так і в Україні [2]. Протягом усього XX ст. відзначається зростання травматизму зі смертельним наслідком, 3 переходом на інвалідність, 3 тимчасовою втратою працездатності. Сьогодні травми займають третє місце серед при-

чин смерті населення, причому переважно працездатного віку [6].

В Україні протягом останніх років становище у сфері охорони праці залишається напруженим. Діюча система управління охороною праці виявилась недостатньо ефективною в умовах сьогодення, тому рівень виробничого травматизму залишається достатньо високим $[1,8]$.

Проблема створення безпечних і нешкідливих умов праці в Україні існувала завжди, про що свідчить статистика нещасних випадків: ще понад 20 


\section{TЕХНІЧНІ НАУКИ}

років тому на виробництві щорічно травмувалося 125 тисяч працівників, 3 них три тисячі гинуло. Тому потребують подальшого дослідження фактори, які впливають на виробничий травматизм і способи зменшення їх шкідливої дії $[3,9]$.

Аналіз останніх досліджень і публікацій, у яких започатковано розв'язання цісї проблеми. В Україні найбільш несприятливі умови праці виявлено у вугільній промисловості, чорній і кольоровій металургії, в сільському господарстві, промисловості будівельних матеріалів, будівництві, транспорті, культурно-соціальній сфері, де знос основних виробничих фондів досягає 65-90\%. Тому вивченню й аналізу стану виробничого травматизму та професійних захворювань в Україні присвятили свої праці такі вчені та науковці: Кобець В. В., Костенко О. М., Пономаренко В. С., Цапко В. Г., Шляховський О. О., Лобас В. І., Кундієв Ю. І., Лисюк М. О., Нагорна А. М., Романенко Н. В., Ткачук К. Н., Сліпо О. О., Дегтяренко Г. Є., Меліс-Шахназаров Л. Ш., Малихін О. В., Таірова Т. М., Шевченко І. В., Саричева А. А., Цибульська О. В. та інші.

Головною метою дослідження $є$ аналіз стану виробничого травматизму та професійних захворювань за галузями нагляду та регіонами України, виявлення причин травматизму та шляхів його запобігання.

Завдання дослідження - вивчити стан виробничого травматизму та професійних захворювань в Україні.

Матеріали і методи досліджень. Порівняльний аналіз стану нещасних випадків та професійних захворювань на підприємствах України за 2015-2017 рр. проводили за офіційними даними робочих органів виконавчої дирекції Фонду соціального страхування України [10] та Державної служби України з питань праці [4].

Для вивчення виробничого травматизму використано масив даних про потерпілих від нещасних випадків на виробництві, зокрема зі смертельними наслідками, в розрізі галузей нагляду та регіонів України, на яких складено акти за формою Н-1. Розподіл кількості професійних захворювань здійснювався згідно з даними актів за формою П-4 за галузями нагляду України.

Результати досліджень. Залежно від соціально-економічної ситуації у країні, стан виробничого травматизму та професійних захворювань тісно пов'язаний iз станом окремих галузей економіки.
Незадовільна організація умов і безпеки охорони праці, порушення технологічної та трудової дисципліни, безвідповідальність керівників підприємств у сучасних умовах господарювання призводить до нещасних випадків на виробництві [7].

Аналіз оперативних даних [4] за 2015-2017 роки свідчить про тенденцію зменшення рівня виробничого травматизму за окремими галузями нагляду в Україні (табл. 1). Протягом 2017 року порівняно з аналогічним періодом 2016 року, кількість травмованих на виробництві зменшилася на 115 осіб або 2,6\% (4313 потерпілих проти 4428 відповідно). Порівняно з 2015 роком рівень виробничого травматизму в 2017 році збільшився на 1,2\% або на 53 особи (4313 потерпілих проти 4260 відповідно).

Збільшення рівня загального травматизму в 2017 році порівняно з 2016 роком спостерігається на підприємствах різних галузей нагляду, а саме: будівництво - на 40 випадків, транспорт - на 29, деревообробна промисловість - на 25, машинобудування - на 23, гірничорудна та нерудна промисловість - на 9, металургійна промисловість на 5, легка та текстильна промисловість - на 1 випадок.

Водночас, більше ніж на 8,1 \% зменшився загальний травматизм у великих травмонебезпечних галузях виробництва, а саме: вугільна промисловість - на 84 випадки, соціально-культурна сфера та торгівля - на 66, агропромисловий комплекс - на 41, хімічна промисловість - на 18, енергетика - на 15, житлово-комунальне господарство - на 12, котлонагляд, підйомні споруди - на 4, зв'язок і нафтогазовидобувна та геологорозвідка - по 3, газова промисловість на 1 випадок.

Порівняно з 2015 роком рівень загального травматизму в 2017 році збільшився в соціальнокультурній сфері та торгівлі - на 53 випадки, вугільній промисловості - на 28, машинобудуванні - на 25, будівництві - на 18, житловокомунальному господарстві - на 14, навтогазовидобувній та геологорозвідці - на 9, енергетиці на 8, котлонагляді, підйомних спорудах і легкій та текстильній промисловості - по 6 випадків. Зменшення виробничого травматизму відбулося в агропромисловому комплексі - на 65 випадків, газовій промисловості - на 13 , хімічній промисловості - на 9, металургійній промисловості на 8, деревообробній промисловості - на 7, гірничорудній та нерудній промисловості - на 6, транспорті і зв’язку - по 3 випадки. 


\section{1. Рівень загального виробничого травматизму за галузями нагляду підприємств Украӥни (2015-2017 рр.), осіб}

\begin{tabular}{|l|c|c|c|c|c|}
\hline \multirow{2}{*}{ Галузь нагляду } & \multirow{2}{*}{2015} & 2016 & 2017 & \multicolumn{2}{|c|}{ Bідхилення, \pm} \\
\cline { 5 - 6 } & & & & $2017-$ & $2017-$ \\
\hline Вугільна & & & 2016 & 2015 \\
\hline Гірничорудна та нерудна & 752 & 864 & 780 & -84 & 28 \\
\hline Нафтогазовидобувна та геологорозвдка & 207 & 192 & 201 & 9 & -6 \\
\hline Енергетика & 113 & 23 & 20 & -3 & 9 \\
\hline Будівництво & 206 & 136 & 121 & -15 & 8 \\
\hline Котлонагляд, підйомні споруди & 10 & 20 & 224 & 40 & 18 \\
\hline Машинобудування & 311 & 313 & 336 & 23 & 25 \\
\hline Металургійна & 268 & 255 & 260 & 5 & -8 \\
\hline Хімічна & 137 & 146 & 128 & -18 & -9 \\
\hline Транспорт & 396 & 364 & 393 & 29 & -3 \\
\hline Зв'язок & 60 & 60 & 57 & -3 & -3 \\
\hline Газова промисловість & 48 & 36 & 35 & -1 & -13 \\
\hline Житлово-комунальне господарство & 141 & 167 & 155 & -12 & 14 \\
\hline Агропромисловий комплекс & 602 & 578 & 537 & -41 & -65 \\
\hline Деревообробна промисловість & 83 & 51 & 76 & 25 & -7 \\
\hline Легка та текстильна промисловість & 17 & 22 & 23 & 1 & 6 \\
\hline Соціально-культурна сфера та торгівля & 898 & 1017 & 951 & -66 & 53 \\
\hline Разом & 4260 & 4428 & 4313 & -115 & 53 \\
\hline
\end{tabular}

Джерело: дані [4].

\section{2. Рівень загального виробничого травматизму за регіонами Украӥни за 2015-2017 рр.}

\begin{tabular}{|l|c|c|c|c|c|c|}
\hline \multirow{2}{*}{ Області } & \multicolumn{2}{|c|}{2015} & \multicolumn{2}{c|}{2016} & \multicolumn{2}{c|}{2017} \\
\cline { 2 - 7 } & осіб & $\%$ & осіб & $\%$ & осіб & $\%$ \\
\hline Дніпропетровська & 608 & 14,3 & 725 & 16,4 & 704 & 16,3 \\
\hline Донецька & 672 & 15,8 & 666 & 15,0 & 608 & 14,1 \\
\hline Запорізька & 285 & 6,7 & 296 & 6,7 & 314 & 7,3 \\
\hline м. Київ & 315 & 7,4 & 331 & 7,5 & 335 & 7,8 \\
\hline Львівська & 224 & 5,3 & 213 & 4,8 & 221 & 5,1 \\
\hline Полтавська & 206 & 4,8 & 199 & 4,5 & 185 & 4,3 \\
\hline Інші регіони & 1950 & 45,7 & 1998 & 45,1 & 1946 & 45,1 \\
\hline Разом & 4260 & 100 & 4428 & 100 & 4313 & 100 \\
\hline
\end{tabular}

Джерело: дані [4].

Аналіз даних щодо виробничого травматизму в 2017 році показує, що понад $94 \%$ травмованих припадає на десять видів нагляду, адаптованих до КВЕД: соціально-культурна сфера та торгівля $23,3 \%$, вугільна промисловість - 19,1\%, агропромисловий комплекс - $13,1 \%$, транспорт $9,6 \%$, машинобудування - 8,2 \%, металургійна промисловість - 6,4\%, будівництво - 5,5\%, гірничорудна та нерудна промисловість $-4,9 \%$, житлово-комунальне господарство $-3,8 \%$, хімічна промисловість $-3,1 \%$, енергетика $-3,0 \%$.
Для наочності відобразимо рівень загального виробничого травматизму за регіонами України в таблиці 2.

Із даних табл. 2 видно, що найбільшу кількість нещасних випадків на виробництві за 20152017 pp. зареєстровано в Дніпропетровській, Донецькій, Запорізькій, Львівській, Полтавській областях та в м. Київ, що складає близько $55 \%$ від загальної кількості травмованих по Україні. 


\section{3. Рівень смертельного виробничого травматизму за галузями нагляду підприємств України (2015-2017 рp.), осіб}

\begin{tabular}{|c|c|c|c|c|c|}
\hline \multirow[b]{2}{*}{ Галузь нагляду } & \multirow[b]{2}{*}{2015} & \multirow[b]{2}{*}{2016} & \multirow[b]{2}{*}{2017} & \multicolumn{2}{|c|}{ Відхилення, \pm} \\
\hline & & & & $\begin{array}{l}2017- \\
2016\end{array}$ & $\begin{array}{l}2017- \\
2015\end{array}$ \\
\hline Вугільна & 19 & 20 & 23 & 3 & 4 \\
\hline Гірничорудна та нерудна & 16 & 23 & 9 & -14 & -7 \\
\hline Нафтогазовидобувна та геологорозвідка & 4 & 5 & 3 & -2 & -1 \\
\hline Енергетика & 18 & 14 & 16 & 2 & -2 \\
\hline Будівництво & 35 & 41 & 54 & 13 & 19 \\
\hline Котлонагляд, підйомні споруди & 1 & 6 & 9 & 3 & 8 \\
\hline Машинобудування & 21 & 19 & 19 & - & -2 \\
\hline Металургійна & 14 & 12 & 13 & 1 & -1 \\
\hline Хімічна & 16 & 10 & 5 & -5 & -11 \\
\hline Транспорт & 54 & 70 & 65 & -5 & 11 \\
\hline Зв'язок & 8 & 1 & 2 & 1 & -6 \\
\hline Газова промисловість & 2 & 2 & 2 & - & - \\
\hline Житлово-комунальне господарство & 14 & 34 & 17 & -17 & 3 \\
\hline Агропромисловий комплекс & 84 & 83 & 75 & -8 & -9 \\
\hline Деревообробна промисловість & 5 & 2 & 7 & 5 & 2 \\
\hline Легка та текстильна промисловість & - & - & 1 & 1 & 1 \\
\hline Соціально-культурна сфера та торгівля & 64 & 58 & 46 & -12 & -18 \\
\hline Разом & 375 & 400 & 366 & -34 & -9 \\
\hline
\end{tabular}

\section{Джерело: дані [4].}

Зростання рівня виробничого травматизму в 2017 році порівняно з 2015 роком відбулося у таких областях: Дніпропетровській - на 96 осіб або $16 \%$, Запорізькій - на 29 осіб або $10 \%$ та м. Київ на 20 осіб або $6 \%$ відповідно. Значне зниження кількості травмованих спостерігалося у Полтавській - на 21 особу або $10 \%$, Донецькій на 64 особи або $9 \%$, Львівській областях - на 3 особи або $1 \%$ і відповідно. Порівняно 3 аналогічним періодом 2016 року рівень загального травматизму за регіонами України знизився на 115 осіб або $3 \%$.

Рівень смертельного виробничого травматизму в Україні за 2017 рік зменшився на 34 особи або $8,5 \%$ (366 загиблих проти 400), порівняно 3 2016 роком та на 9 осіб або 2,4\% (366 загиблих проти 375) порівняно з 2015 роком (табл. 3).

2017 року збільшення рівня смертельного травматизму порівняно з 2016 роком відбулося на підприємствах таких галузей нагляду: будівництво - на 13 випадків, деревообробна промисловість на 5, вугільна промисловість і котлонагляд, підйомні споруди - по 3, енергетика - на 2, металургійна промисловість, зв'язок і легка та текстильна промисловість - по 1 випадку. Зменшення рівня смертельного травматизму спостерігається на під- приємствах таких галузей нагляду: житловокомунальне господарство - на 17 випадків, гірничорудна та нерудна промисловість - на 14, соціально-культурна сфера та торгівля - на 12, агропромисловий комплекс - на 8, хімічна промисловість - на 5, нафтогазовидобувна та геологорозвідка - на 2 випадки. В машинобудуванні і газовій промисловості рівень смертельного травматизму в 2017 році був на рівні 2016 року і становив 19 i 2 випадки відповідно.

Порівняно з 2015 роком рівень смертельного травматизму в 2017 році збільшився в будівництві - на 19 випадків, транспорті - на 11, котлонагляді, підйомних спорудах - на 8, вугільній промисловості - на 4, житлово-комунальному господарстві на 3 , деревообробній промисловості - на 2 , легкій та текстильній промисловості - на 1 випадок. Зменшення смертельного травматизму відбулося в соціально-культурній сфері та торгівлі - на 18 випадків, хімічній промисловості - на 11 , агропромисловому комплексі - на 9, гірничорудній та нерудній промисловості - на 7, зв' язку - на 6, енергетиці і машинобудуванні - по 2, нафтогазовидобувній та геологорозвідці і металургійній промисловості по 1 випадку. Лише в газовій промисловості рівень 


\section{TEХНIЧНI НАУКИ}

смертельного травматизму в 2017 році був на рівні 2015 року і становив 2 випадки.

Стосовно травматизму зі смертельними наслідками, то близько 84 \% загиблих також припадає на вищезазначені сім видів нагляду, адаптованих до КВЕД, а саме: агропромисловий комплекс $24,4 \%$, транспорт - 21,2 \%, будівництво - 17,6 \%, соціально-культурну сферу та торгівлю - 15,0 \%, вугільну промисловість - 7,5 \%, машинобудування - 6,2 \%, житлово-комунальне господарство $5,5 \%$, енергетика - 5,2 \%, металургійна промисловість $-4,2 \%$.

За регіонами України найбільшу кількість нещасних випадків на виробництві зі смертельними наслідками в 2015-2017 pp. зареєстровано в Дніпропетровській, Донецькій, Київській, Львівській, Харківській, Полтавській і Одеській областях та в м. Київ, що складає 57,0 \%, 50,0 і 58,3 \% відповідно від загальної кількості смертельно травмованих по Україні (табл. 4).

Зростання рівня смертельного виробничого травматизму в 2017 році порівняно з 2015 роком відбулося у Львівській області - на 11 осіб або 1,5 рази та в м. Київ - на 12 осіб або 1,4 рази відповідно. Значне зниження кількості травмованих спостерігалося у Дніпропетровській на 8 осіб або 17 \%, Донецькій - на 5 осіб або 14 \%, Київській - на 3 особи або $13 \%$, Одеській і Полтавській - на 3 особи або $16 \%$ відповідно, Харківській - на 2 особи або $10 \%$. У порівнянні 3 аналогічним періодом 2016 року рівень смертельного виробничого травматизму за регіонами України знизився на 34 особи або $9 \%$.

Науково-технічний прогрес, докорінно змінюючи характер праці, породжує нові фактори виробничого середовища, які несприятливо впливають на працюючих. У зв'язку 3 цим професійна захворюваність є однією із проблемних сфер на підприємствах України [3]. Кількість випадків професійних захворювань на виробництві в Україні за 2015-2017 pp. [10] зображено на рисунку.

Із рисунку видно, що в 2015 році кількість професійних захворювань на виробництві в Україні становила 1764 випадків. У 2016 році порівняно 3 2015 роком кількість професійних захворювань зменшилась на 9,1\%, або на 161 випадок (з 1764 до 1603). 2017 року кількість професійних захворювань порівняно 32016 роком збільшилася на 21,7 \%, або на 348 випадків (з 1603 до 1951).

У структурі професійних захворювань, у середньому за 2015-2017 pp., перше місце належить хворобам органів дихання - 44,0 \% від загальної кількості по Україні (779 випадків). На другому місці - захворювання опорно-рухового апарату (радикулопатії, остеохондрози, артрити, артрози) 33,6 \% або 590 випадків. Третє місце за вібраційною хворобою - 8,1 \% або 143 випадки, а четверте місце за хворобами слуху - 5,8 \% або 107 випадків. Інші види хвороб у структурі професійних захворювань становлять 8,5 \% або 154 випадки.

Найбільше професійних захворювань сталося в галузі добувної промисловості і розробленні кар'єрів, а також у таких галузях як: виробництво машин і устаткування; металургійне виробництво, виробництво готових металевих виробів, крім машин і устаткування; інші види переробної промисловості, ремонт і монтаж машин і устаткування; охорона здоров'я; виробництво коксу та продуктів нафтоперероблення.

\section{4. Рівень смертельного виробничого травматизму за регіонами Украйни за 2015-2017 рр.}

\begin{tabular}{|c|c|c|c|c|c|c|}
\hline \multirow{2}{*}{ Області } & \multicolumn{2}{|c|}{2015} & \multicolumn{2}{|c|}{2016} & \multicolumn{2}{|c|}{2017} \\
\hline & осіб & $\%$ & осіб & $\%$ & осіб & $\%$ \\
\hline Дніпропетровська & 47 & 12,5 & 47 & 11,8 & 39 & 10,7 \\
\hline Донецька & 36 & 9,6 & 29 & 7,3 & 31 & 8,5 \\
\hline Київська & 23 & 6,1 & 25 & 6,2 & 20 & 5,5 \\
\hline м. Київ & 29 & 7,7 & 19 & 4,7 & 41 & 11,2 \\
\hline Львівська & 22 & 5,9 & 22 & 5,5 & 33 & 9,0 \\
\hline Одеська & 18 & 4,8 & 18 & 4,5 & 15 & 4,1 \\
\hline Полтавська & 19 & 5,1 & 17 & 4,2 & 16 & 4,4 \\
\hline Харківська & 20 & 5,3 & 23 & 5,8 & 18 & 4,9 \\
\hline Інші регіони & 161 & 43,0 & 200 & 50,0 & 153 & 41,7 \\
\hline Разом & 375 & 100 & 400 & 100 & 366 & 100 \\
\hline
\end{tabular}

Джерело: дані [4]. 


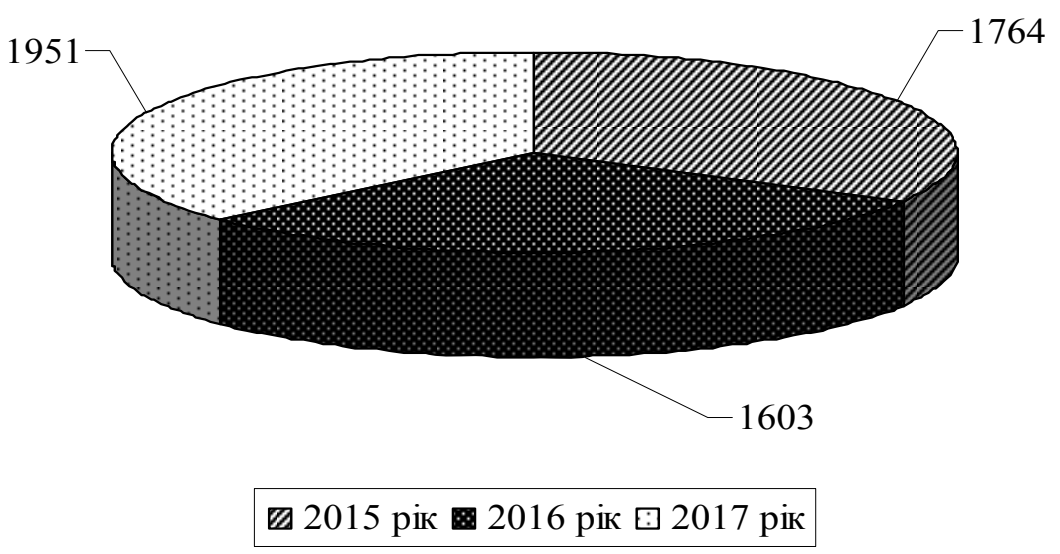

Рис. Кількість випадків професійних захворювань на виробництві в Украӥні за 2015-2017 рр.

Докерело: дані [10].

Висновок. Проведені дослідження сучасного стану виробничого травматизму в Україні свідчать про те, що рівень загального травматизму за галузями нагляду і регіонами України в 2017 році зменшується порівняно з 2016 роком, проте спостерігається деяка тенденція до збільшення травматизму порівняно з 2015 роком. Найбільш травмонебезпечними галузями залишаються соціально-культурна сфера та торгівля, вугільна промисловість, агропромисловий комплекс,

\section{БІБЛІОГРАФІЯ}

1. Березовський А. П., Прокопенко Е. В. Удосконалення методики оцінки професійних ризиків на робочому місці. Вісник Уманського нащіонального університету садівництва. 2013. № 1-2. C. 241-243.

2. Березовський А. П., Прокопенко Е. В., Tpyc O.M. Стан виробничого травматизму на виробництвах Черкаської області. Збірник наук. пр. Уманського НУС. 2015. Вип. 87. Ч 1. C. 73-79.

3. Гордійчук Л. М. Аспекти виробничого травматизму та професійна захворюваність. Науковий вісник ЛНУВМБТ імені С. З. Гжииького. 2017. № 76, т. 19. С. 136-138.

4. Державна служба України з питань праці. URL : http://dsp.gov.ua/ statystychni-danivyrobnychoho-travma-2.

5. Зварич О. М. Аналіз стану виробничого травматизму та професійних захворювань на підприємствах України. Студентський вісник Національного університету водного господарства та природокористування. 2017. №. 1. Вип. 7. С. 44-46. транспорт, машинобудування, металургійна промисловість, будівництво, хімічна промисловість та енергетика. Зменшився рівень смертельного травматизму на підприємствах 3 аналогічними періодами дослідження. 2017 року спостерігається зростання кількості професійних захворювань на виробництві порівняно 3 попередніми роками. Найбільше професійних захворювань сталося в галузі добувної промисловості і розробленні кар'єрів.

6. Кундієв Ю. І., Лисюк М. О., Нагорна А. М., Романенко Н. В. Стан виробничого травматизму та наглядової діяльності за охороною праці в Україні. Український журнал з проблем медииини прачі. 2008. № 2. Вип. 14. С. 3-14.

7. Малихін О. В., Таірова Т. М., Сліпачук О. А. Особливості виробничого травматизму і наглядової діяльності в Україні в умовах економічної кризи. Інформачійний бюлетень з охорони прачі. 2015. № 1. C. 45-51.

8. Пахомов Р. І., Гасій Г. М., Білоус І. О., Лавpy T. B. Аналіз, прогнозування та профілактика травматизму з важкими наслідками. Збірник наук. пр. Харківського університету Повітряних Сил. 2015. № 2. Вип. 43. С. 139-144.

9. Рябенька М. О. Сучасний стан та динаміка виробничого травматизму у промисловості України. Збірник наук. пр. Віннищького НАУ. 2014. № 1. Вип. 84. С. 37-41.

10. Фонд соціального страхування України. URL : http://fssu.gov.ua/fse/control/main/uk/publish /article/ 951811. 


\section{REFERENCES}

1. Berezovskyi, A. P., Prokopenko, E. V. (2013). Udoskonalennya metodyky otsinky profesiynykh ryzykiv na robochomu mistsi [Improvement of the methodology of professional risk assessment at the workplace]. Visnyk Umanskoho natsionalnoho universytetu sadivnytstva, № 1-2, pp. 241-243 [In Ukrainian].

2. Berezovskyi, A. P., Prokopenko, E. V., Trus, O. M. (2015). Stan vyrobnychoho travmatyzmu na vyrobnytstvakh Cherkaskoyi oblasti [The state of occupational injuries at the enterprises of Cherkasy region]. Zbirnyk nauk. pr. Umanskoho NUS, 87 (1), pp. 73-79 [In Ukrainian].

3. Hordiychuk, L. M. (2017). Aspekty vyrobnychoho travmatyzmu ta profesiyna zakhvoryuvanist [Aspects of occupational injury and occupational disease]. Naukovyy visnyk LNUVMBT imeni $\begin{array}{llll}\text { S. Z. Gzhytskoho, } \quad 76 & \text { (19), } & \text { pp. } & 136-138\end{array}$ [In Ukrainian].

4. Derzhavna sluzhba Ukrayiny $\mathrm{z}$ pytan pratsi [State Labor Service of Ukraine]. URL : http://dsp.gov.ua/ statystychni-dani-vyrobnychohotravma-2 [In Ukrainian].

5. Zvarych, O. M. (2017). Analiz stanu vyrobnychoho travmatyzmu ta profesiynykh zakhvoryuvan na pidpryyemstvakh Ukrayiny [Analysis of the condition of occupational injuries and occupational diseases at the enterprises of Ukraine]. Student skyy visnyk Natsionalnoho universytetu vodnoho hospodarstva ta pryrodokorystuvannya, 1 (7), pp. 44-46 [In Ukrainian].
6. Kundiyev, Yu. I., Lysyuk, M. O., Nahorna, A. M., Romanenko, N. V. (2008). Stan vyrobnychoho travmatyzmu ta nahlyadovoyi diyalnosti za okhoronoyu pratsi v Ukrayini [The state of occupational injury and surveillance activities in Ukraine]. Ukrayinskyy zhurnal z problem medytsyny pratsi, 2 (14), pp. 3-14 [In Ukrainian].

7. Malykhin, O. V., Tairova, T. M., Slipachuk, O. A. (2015). Osoblyvosti vyrobnychoho travmatyzmu i nahlyadovoyi diyalnosti v Ukrayini $\mathrm{v}$ umovakh ekonomichnoyi kryzy [Peculiarities of Occupational Injuries and Supervisory Activity in Ukraine in the Conditions of the Economic Crisis]. Informatsiynyy byuleten z okhorony pratsi, 1, pp. 45-51 [In Ukrainian].

8. Pakhomov, R. I., Hasiy, H. M., Bilous, I. O., Lavru, T. V. (2015). Analiz, prohnozuvannya ta profilaktyka travmatyzmu $\mathrm{z}$ vazhkymy naslidkamy [Analysis, prediction and prevention of injuries with severe consequences]. Zbirnyk nauk. $p r$. Kharkivskoho universytetu Povitryanykh Syl, 2 (43), pp. 139-144 [In Ukrainian].

9. Ryabenka, M. O. (2014). Suchasnyy stan ta dynamika vyrobnychoho travmatyzmu u promyslovosti Ukrayiny [Current state and dynamics of occupational injuries in the industry of Ukraine]. Zbirnyk nauk. pr. Vinnytskoho NAU, 1 (84), pp. 3741 [In Ukrainian].

10. Fond sotsialnoho strakhuvannya Ukrayiny [Social Insurance Fund of Ukraine]. URL : http://fssu.gov.ua/fse/ control/main/uk/publish/article/951811 [In Ukrainian].

Березовский А. П., Трус А. Н., Прокопенко Е. В. Состояние производственного травматизма и профессиональных заболеваний в Украине

Цель статьи заключается в том, чтобы исследовать состояние производственного травматизма и профессиональных заболеваний в Украине, выявить причины травматизма и пути его предупреждения.

Методика исследования. Для определения количественных показателей, характеризующих общий уровень производственного травматизма (акты за формой $H-1$ ) и профессиональных заболеваний (акты за формой П-4) использовали статистический метод.

Результаты исследования. Проведен сравнительный анализ производственного травматизма и профессиональных заболеваний на производстве по отраслям надзора и регионами Украины за 20152017 годы. Установлено, что показатели производственного травматизма, в т.ч. со смертельным исходом имеют тенденцию к снижению. В 2017 году количество травмированных на производстве по сравнению с 2016 годом уменьшилась на 115 человек, а с 2015 годом наблюдалось увеличение травмированных на 53 человека. Уровень смертельного травматизма в 2017 году уменьшился на 34 и 9 человек соответственно. Приведены данные о росте количества профессиональных заболеваний на производстве в 2017 году по сравнению с предьдущими годами. Установлено, что наибольшее количество профессиональных заболеваний произошло в области добывающей промышленности $и$ разработке карьеров. 


\section{TEХНІЧНІ НАУКИ}

Элементы научной новизны. Установлено, что показатели производственного травматизма, в т.ч. со смертельным исходом, имеют тенденцию к снижению. Наблюдается рост количества профессиональных заболеваний на производстве по сравнению с предыдущзими годами.

Практическая значимость. Наиболее травмоопасными отраслями остаются сочиальнокультурная сфера и торговля, угольная промышленность, агропромышленный комплекс, транспорт, машиностроение, металлургическая промыиленность, строительство, химическая промышленность и энергетика.

Ключевые слова: производственный травматизм, смертельный травматизм, отрасли надзора, несчастные случаи, профессиональные заболевания, охрана труда.

Березовский Андрей Павлович - кандидат сельскохозяйственных наук, доцент, заведующий кафедрой прикладной инженерии и охраны труда, Уманский национальный университет садоводства, ул. Институтская, 1, г. Умань, Черкасская область, 20300, Украина, e-mail: kafedrapi@gmail.com.

Трус Александр Николаевич - кандидат сельскохозяйственных наук, доцент, доцент кафедры прикладной инженерии и охраны труда, Уманский национальный университет садоводства, ул. Институтская, 1, г. Умань, Черкасская область, 20300, Украина, e-mail: alex_trus@ukr.net.

Прокопенко Эдуард Васильевич - кандидат сельскохозяйственных наук, доцент, доцент кафедры прикладной инженерии и охраны труда, Уманский национальный университет садоводства, ул. Институтская, 1, г. Умань, Черкасская область, 20300, Украина, e-mail: proked@ukr.net.

\section{Berezovskyi A. P., Trus O. M., Prokopenko Ye. V. The state of industrial traumatism and professional diseases in Ukraine}

The purpose of the article is to investigate the state of industrial traumatism and professional diseases in Ukraine, to identify the causes of injuries and ways to prevent them.

Methods of the research. We used the statistical method to determine the quantitative indicators characterizing the general level of industrial injuries (statements according to $H-1$ form) and professional diseases (statements according to $\Pi-4$ form).

The research results. The article presents the comparative analysis of the level of occupational injuries and professional diseases in the industries according to field of survey and the regions of Ukraine over the period from 2015 to 2017. It has been established that the indices of industrial injuries including fatal accidents show a declining tendency. In 2017 as compared with the same period in 2016, the number of injured employees at workplaces decreased by 115 persons or by 2.6\% (4313 injured as compared to 4428 respectively). In comparison with 2015, the level of workplace injuries in 2017 increased by $1.2 \%$ or 53 persons (4313 injured as compared to 4260 correspondingly).

There has been an increase in the injury rate at the enterprises of different branches, namely: in socialcultural sphere and trade, coal-mining industry, machine-building, construction, housing and utility sector. Workplace injury level increased in 2017 as compared to 2015 in Dnipropetrovsk, Zaporizhzhia regions and Kyiv.

The level of fatal workplace injuries in Ukraine in 2017 decreased by 34 persons or $8.5 \%$ (366 fatal casualties against 400) compared to 2016 and by 9 persons or $2.5 \%$ (366 fatal accidents against 375) compares to 2015. In comparison to 2015, the level of fatal injuries in 2017 increased in the construction, transport, boiler maintenance, lifting devices. The highest level of fatal accidents at work places over the period of 2015-2017 was recorded in Dnipropetrovsk, Donetsk, Kyiv, Lviv, Kharkiv, Poltava, Odesa regions.

In the structure of professional diseases those of the respiratory system rank first (779 cases). Muscularskeletal disorders (590 cases) rank second, vibration disease takes the third place (143 cases) and hearing disorders are in the fourth place (107 cases). Other diseases in the structure of professional illnesses make up $8.5 \%$. It has been established that the greatest number of professional diseases was in the extractive industry and quarry development.

The elements of scientific novelty. It has been established that the indicators of industrial injuries, including fatal, tend to decrease. There has been an increase in the number of occupational diseases at work as compared with the previous years.

Practical importance. Social-cultural sphere and trade, coal-mining industry, agro-industrial complex, transport, machine-building, metallurgy, construction, chemical industry, and power engineering remain the most traumatic industries. 
Key words: industrial traumatism, fatal injury accidents, fields of survey, accidents, professional diseases, occupational health.

Berezovskyi Andrii Pavlovych - Candidate (Ph.D.) of Agricultural Sciences, Associate Professor, Head of the Department of Applied Engineering and Occupational Health, Uman National University of Horticulture, 1, Instytutska st., Uman, Cherkasy region, 20300, Ukraine, e-mail: kafedrapi@gmail.com.

Trus Oleksandr Mykolaiovych - Candidate (Ph.D.) of Agricultural Sciences, Associate Professor, Associate Professor of the Department of Applied Engineering and Occupational Health, Uman National University of Horticulture, 1, Instytutska st., Uman, Cherkasy region, 20300, Ukraine, e-mail: alex_trus@ukr.net.

Prokopenko Eduard Vasylovych - Candidate (Ph.D.) of Agricultural Sciences, Associate Professor, Associate Professor of the Department of Applied Engineering and Occupational Health, Uman National University of Horticulture, 1, Instytutska st., Uman, Cherkasy region, 20300, Ukraine, e-mail: proked@ukr.net.

Стаття надійшла до редакції 25.02.2019 р.

Бібліографічний опис для цитування :

Березовський А. П., Трус О. М., Прокопенко Е. В. Стан виробничого травматизму та професійних захворювань в Україні. Вісник ПДАА. 2019. № 1. С. 241-249.

DOI 10.31210/visnyk2019.01.29

(C) Березовський Андрій Павлович, Трус Олександр Миколайович, Прокопенко Едуард Васильович, 2019 